\title{
Azerbaijani Language
}

National Cancer Institute

\section{Source}

National Cancer Institute. Azerbaijani Language. NCI Thesaurus. Code C153847.

A T urkic language spoken primarily by the Azerbaijanis, mainly in Transcaucasia and Iranian Azerbaijan. 